University of Nebraska - Lincoln

DigitalCommons@University of Nebraska - Lincoln

10-1-2001

\title{
Corn stalk nitrate concentration profile: Implications for the end- of-season stalk nitrate test
}

Wally Wilhelm

University of Nebraska-Lincoln, wally.wilhelm@ars.usda.gov

Gary E. Varvel

University of Nebraska-Lincoln, gevarvel@windstream.net

James S. Schepers

University of Nebraska-Lincoln, james.schepers@gmail.com

Follow this and additional works at: https://digitalcommons.unl.edu/usdaarsfacpub

Part of the Agricultural Science Commons

Wilhelm, Wally; Varvel, Gary E.; and Schepers, James S., "Corn stalk nitrate concentration profile: Implications for the end-of-season stalk nitrate test" (2001). Publications from USDA-ARS / UNL Faculty. 78.

https://digitalcommons.unl.edu/usdaarsfacpub/78

This Article is brought to you for free and open access by the U.S. Department of Agriculture: Agricultural Research Service, Lincoln, Nebraska at DigitalCommons@University of Nebraska - Lincoln. It has been accepted for inclusion in Publications from USDA-ARS / UNL Faculty by an authorized administrator of DigitalCommons@University of Nebraska - Lincoln. 


\title{
Corn stalk nitrate concentration profile: Implications for the end-of- season stalk nitrate test
}

\author{
W. W. Wilhelm, G. E. Varvel, and J. S. Schepers \\ Soil and Water Conservation Research Unit, Agricultural Research Service, United States Dep. of Agriculture, 120 \\ Kiem Hall, Univeristy of Nebraska, Lincoln, Nebraska, 68583-0934, United States, wwilhelm1@unl.edu
}

Key words: corn, end-of-season stalk nitrate test, $\mathrm{N}$ nutrition, nitrate concentration, Zea mays L.

\begin{abstract}
The end-of-season corn (Zea mays L.) stalk nitrate-N test was developed as a post-mortem to determine if excessive or insufficient $\mathrm{N}$ was available to the corn crop during the latter part of the season. The stalk section specified for the test was very specific, the $20 \mathrm{~cm}$-long section between 15 and $35 \mathrm{~cm}$ above the soil. Under production conditions, it may not always be possible to collect this precise stalk section. The objective of this study was to determine how nitrate concentration varied within the stalk from the soil level to the ear node, and how this variation could affect interpretations of the stalk nitrate test. Field grown $\left(140 \mathrm{~kg} \mathrm{~N} \mathrm{ha}^{-1}\right)$ corn stalks were collected and separated into phytomers (the node plus leaf, internode, and bud developing from it). Phytomers were further divided into six segments; the node and five equal length segments of the internode. All samples were analysed for $\mathrm{NO}_{3}-\mathrm{N}$ with a nitrate-ion specific electrode after extraction with $0.04 M\left(\mathrm{NH}_{4}\right)_{2} \mathrm{SO}_{4}$. Nitrate concentrations of individual samples varied from less than 100 to greater than $8000 \mathrm{mg} \mathrm{NO}-\mathrm{N}$ $\mathrm{kg}^{-1}$ dry weight, and increased down the stalk from ear to soil. Generally, the nitrate concentrations of segments within a phytomer were similar. These results indicated new critical values, approximately $35 \%$ greater than the original ones, may be needed to determine if limiting or excessive amounts of $\mathrm{N}$ were available to the crop, i.e. 950 vs. 700 and 2700 vs. 2000 mg NO $\mathrm{NO}_{3}-\mathrm{N} \mathrm{kg}^{-1}$ for insufficient and excessive levels, respectively. However, the general interpretation of test would remain unchanged because stalk nitrate concentrations vary so widely under field conditions from less than 100 to greater than $5000 \mathrm{mg} \mathrm{NO}-\mathrm{N} \mathrm{kg}^{-1}$.
\end{abstract}

\section{Introduction}

The end-of-season corn (Zea mays L.) stalk nitrate-N test (hereafter referred to as stalk nitrate test) was proposed by Binford et al. (1990) as a method of determining if excessive or insufficient $\mathrm{N}$ was available to the corn crop during the latter part of the season. In the test, $20-\mathrm{cm}$ sections of corn stalks (between 15 and $35 \mathrm{~cm}$ above the soil) are collected from several plants, dried, ground, and analysed for nitrate-N. Nitrate-N concentrations less than $700 \mathrm{mg} \mathrm{kg}^{-1}$ dry stalk tissue indicated that available $\mathrm{N}$ limited grain yield whereas concentrations greater than $2,000 \mathrm{mg} \mathrm{kg}^{-1}$ indicated excessive $\mathrm{N}$ was available to the crop (Binford et al., 1992). Other researchers have evaluated the test and concurred that stalk nitrate concentrations greater than $2000 \mathrm{mg} \mathrm{kg}^{-1}$ indicated that excessive $\mathrm{N}$ was available to the crop (Varvel et al., 1997). These studies suggested that the stalk nitrate assay could be used as a post-mortem to determine if yield-limiting or excessive $\mathrm{N}$ was present to guide future fertilizer- $\mathrm{N}$ management, thereby improving profitability and reducing environmental degradation.

To be a useful crop management tool, methods for collecting and analysing samples must be straightforward and reasonably flexible so producers and consultants can adapt to field conditions as they gather samples. It is unrealistic to assume that samples will always be exactly $20 \mathrm{~cm}$ long and can always be collected between 15 and 35 $\mathrm{cm}$ above the ground under field situations. The objective of this study was to determine how stalk nitrate test results and interpretations would be affected if samples were collected from a portion of the stalk different from that specified by Binford et al. (1990).

\section{Materials and methods}

Stalks were collected, after physiological maturity, from a rain fed field of corn gown with $140 \mathrm{~kg} \mathrm{~N} \mathrm{ha}^{-1}$. Two plants were collected from each of 10 replications. Ears and leaf blades were removed from the stalks in the field and the portion of the stalk above the ear node was discarded. Stalks were cut at the soil surface, labelled and dried at $60^{\circ} \mathrm{C}$. Leaf sheaths were removed from the stalks. Dried stalks were divided and numbered by phytomer unit (internode and subtending node, see Figure 1). Phytomer units were further divided into nodes and internodes, and internodes were subsequently divided into five equal length segments. Segments from the same relative position on the plant (i.e., same phytomer and same segment within the phytomer) from the two plants in each replication were combined and ground to pass a 2-mm screen. Nitrate-N concentration, in a $0.25 \mathrm{~g}$ samples, was determined with a nitrate-ion specific electrode after extraction with $50 \mathrm{~mL}$ of $0.04 M\left(\mathrm{NH}_{4}\right)_{2} \mathrm{SO}_{4}$ (Wilhelm et al., 2000). Analysis of variance (Proc MIXED, Littell et al., 1996) was used to determine if phytomer, tissue type (node vs. internode), and segment within internode differed in nitrate- $\mathrm{N}$ concentration.

\section{Results}

Across all plant parts, nitrate concentrations varied from less than $100 \mathrm{mg} \mathrm{NO}_{3}-\mathrm{N} \mathrm{kg}^{-1}$ dry weight to greater than $8000 \mathrm{mg} \mathrm{NO}-\mathrm{N} \mathrm{kg}^{-1}$ dry weight. Analyses showed that 
tissue types (node vs. internode), phytomers, and segments were significant sources of variation for nitrate-N concentration. Their interaction was not significant suggesting that although nitrate concentration differed with phytomer and segment, the pattern was similar among segments within all phytomers (Table 1).

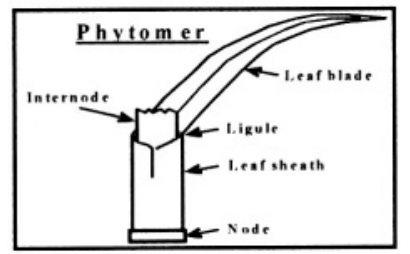

Figure 1. The phytomer is the basic repeating building block of the grass shoot and consists of four tissues, the node and leaf, internode, and axillary bud derived (above) from that node. The axillary bud in this diagram of the phytomer is hidden from view by the leaf sheath.

Table 1. Analysis of variance for nitrate- $\mathrm{N}$ concentration in seyeral phytomers and segments of the corn stalks.

\begin{tabular}{lrrr}
\hline \multicolumn{1}{c}{ Source of variation } & $\begin{array}{c}\text { Degrees of } \\
\text { freedom }\end{array}$ & F-value & $\begin{array}{c}\text { Probability of a } \\
\text { greater } F\end{array}$ \\
\hline Phytomer & 3 & 361 & 0.0001 \\
Segment & 5 & 4 & 0.0039 \\
Phytomer $x$ Segment & 15 & 1 & 0.4751 \\
\hline
\end{tabular}

Table 2. Mean nitrate-N concentration in several phytomers, divided into several segments, of corn stalks.

\begin{tabular}{|c|c|c|c|c|c|}
\hline \multirow[t]{3}{*}{ Segment $^{\top}$} & \multicolumn{4}{|c|}{ Phytomer ${ }^{2}$} & \multirow[t]{2}{*}{ Mean } \\
\hline & $\mathrm{S}+1$ & $\mathrm{~S}+2$ & E-2 & E-1 & \\
\hline & \multicolumn{5}{|c|}{ Nitrate- $\mathrm{N}$ concentration $\left(\mathrm{mg} \mathrm{NO}_{3}-\mathrm{N} \mathrm{kg}^{-1}\right)$} \\
\hline 5 & 3906 & 2261 & 126 & 146 & 1610 \\
\hline 4 & 4456 & 2820 & 155 & 93 & 1881 \\
\hline 3 & 4796 & 3304 & 189 & 105 & 2098 \\
\hline 2 & 5026 & 3870 & 332 & 124 & 2338 \\
\hline 1 & 4699 & 3628 & 423 & 163 & 2228 \\
\hline Node & 4657 & 3643 & 382 & 175 & 2214 \\
\hline Mean & 4590 & 3254 & 268 & 134 & 2061 \\
\hline
\end{tabular}

' Stalk portions of each plyytomer were divided into six segments, the node and five equal length segments of the internode. Segments were numbered upward from the node

${ }^{2}$ Phytomer $\mathrm{S}+1$ was the first phytomer above the soil surface, Phytomer $\mathrm{S}+2$ was the second above the soil, Phytomer E-2 was second below the ear, and Phytomer E-I was immediately below the ear.

Since not all plants within a sample had the same number of phytomers between the soil surface and ear, a continuous description of $\mathrm{NO}_{3}-\mathrm{N}$ concentration for the entire stalk was difficult to produce. For comparison purposes, we report $\mathrm{NO}_{3}-\mathrm{N}$ concentrations for only four phytomers, the two closest to the soil and the two immediately subtending the ear. Depending on the plant, zero to two phytomers may have existed between the phytomers near the soil and ear. As a result, nitrate profiles reported here (Table 2) appear to have a discontinuity that may not exist if data from all phytomers were available. Following the sampling procedures defined by Binford $e t$ al. (1990) for the stalk nitrate test, the second phytomer above the soil $(\mathrm{S}+2)$ would most likely be sampled.

The first two phytomers below the ear (E-1 and E-2) did not differ in nitrate concentration, but phytomers $\mathrm{S}+1$ and $\mathrm{S}+2$ differed from the former two and also differed from each other (Table 2). Nitrate concentration increased gradually moving down the stalk from the ear to the soil. Nitrate concentration in node tissue was similar to that of internode tissue in phytomers E-1, E-2, and S+l. However in phytomer $\mathrm{S}+2$, the nitrate- $\mathrm{N}$ concentration in the upper two segments (4 and 5) was less than in the node tissue (p $<0.05)$. Nitrate-N concentration increased linearly as phytomers were further from the ear $(\mathrm{p}<0.0001)$. Likewise, $\mathrm{NO}_{3}-\mathrm{N}$ concentration of segments, within phytomers, increased linearly as they neared the node $(\mathrm{p}<$ $0.001)$.

\section{Discussion}

These results indicated that reasonable care must be taken in collecting field samples for the stalk nitrate test. If samples are collected closer to the soil than described in the original procedure $(<15 \mathrm{~cm}$ above the soil), the resulting analyses will likely produce greater nitrate-N concentrations. As a result, the critical values suggested by Binford et al. (1990, 1992) may have to be adjusted upward. Data from this initial study with an adequate to excessive $\mathrm{N}$ rate (N application, $140 \mathrm{~kg} \mathrm{ha}^{-1}$; yield $6.35 \mathrm{Mg}$

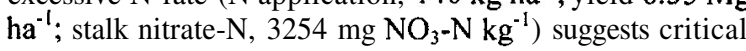
values may need to be increased by about $35 \%$ (comparison of $\mathrm{S}+2$ to $\mathrm{S}+1$ in Table 2). New critical values would be about 950 and $2700 \mathrm{mg} \mathrm{NO}_{3}-\mathrm{N} \mathrm{kg}^{-1}$ for yieldlimiting and excessive levels of $\mathrm{N}$ [compared to 700 and $2000 \mathrm{mg} \mathrm{NO}-\mathrm{N} \mathrm{kg}^{-1}$, respectively, as reported by Binford et al. (1990)]. Further research, with an array of $\mathrm{N}$ rates from yield limiting through excessive, will be required to accurately establish new values. However, interpretation and management decisions based on samples collected from stalk segments nearer the soil and new critical values would be similar to interpretations and decisions based on samples collected as described by Binford et al. (1990).

In fact, collecting samples from segments nearer the soil surface may offer a level of assurance because change in nitrate concentration was greater as samples were collected closer to the ear. Also because nitrate-N concentration declined rapidly in phytomers nearer the ear, field modification of collection procedures to acquire stalk sections more than $30 \mathrm{~cm}$ above the ground may result in inappropriate future $\mathrm{N}$ management procedures from a yield/profitability or environmental standpoint.

\section{References}

Binford GD, Blackmer AM and El-Hout NM 1990 Agron. J. 82, 124-129. Binford GD, Blackmer AM and Meese BG 1992 Agron. J. 84, 881-887. Littell RC, Milliken GA, Stroup WW and Wolfinger RW 1996 SAS System for Mixed Models. SAS Institute, Inc., Cray, NC (USA). Varvel GE, Schepers JS and Francis DD 1997 J. Agric. Prod. 10, 147-151. Wilhelm WW, Arnold SL and Schepers JS 2000 Agron. J. 92, 186-189. 